\title{
Des Moines Street Transit ${ }^{1}$
}

By W. F. McGlothlen

In July 1950, I completed forty-six years of service with the Des Moines Railway Company and its predecessors. I have seen this utility grow and expand from a one-horse system operating single-truck street cars propelled by either horses or mules, with straw on the floor to. keep your feet warm, and no vestibules for the drivers, to its present modern system with luxurious curbliners containing electric heat, upholstered seats, enclosed and heated vestibules for the driver, and a speed of operation that is at least eight or nine times that of the first electric car ever operated in Des Moines.

Few men are now living who were in Des Moines when on January 11, 1868, soon after the Civil war, the first horse car started operations with Dr. M. P. Turner behind the reins. ${ }^{2}$ Dr. Turner was the guiding genius and president of the new company. Associated with him in its formation were Jefferson Polk and other hopeful and enterprising Des Moines business men.

The first horse car ran from the Polk county court house to the foot of Capitol Hill on the east side. Wooden ties were laid on the top of muddy streets and the rail was a flat strip of iron with a three-foot six inch gauge-a so-called narrow-gauge track-compared to the ninety-pound $\mathrm{T}$ rail now used and the wide gauge of four-foot eight inches. The horse cars were

${ }^{1}$ This article was prepared by Mr. McGlothlen to be presented by him at the annual meeting of the Des Moines Pioneer club in January, 195l, but illness prevented his attending. It was read on the program by his son, Harold McGlothlen.

'In the earlier period of Des Moines history, Dr. Turner had operated toll bridges across the Des Moines river, until the charge for passage of pedestrians and vehicles over the bridges was abolished by the city council. 
wonderful to behold. They were brilliantly painted and were all dolled up with a lot of ginger bread and fancy scroll work both inside and out. No heating facilities were provided, but the company was kind enough in the winter to scatter straw over the floor. If your feet were not too large, you could bury them in the straw and then pray that they would not freeze.

A public celebration started the service with a bang. Many speeches were made praising Dr. Turner, Jefferson Polk and his associates for their civic interest and business foresight, and predicting a brilliant and profitable future for this "tremendous advance in civic progress."

In 1876, a track was laid on Walnut street, operated with horse cars, thus increasing the mileage of the railway system to two and one-quarter miles. In that year there were three companies running with a fleet of ten horses in daily use.

No definite schedules were maintained, and many times drivers would stop their cars without any rhyme or reason. Many times service was held up due to cattle roaming the streets in the vicinity served, and the driver had to stop and chase them off the track before he could proceed.

Johnson Brigham in his "History of Des Moines and Polk County", tells the amusing tale of a horse car driver noticing a dog fight near by, jumped off his car and refereed the fight while twenty passengers joined him as spectators. After the fight was over, the car proceeded on its tortuous journey. Passengers of the new system were very helpful. Whenever a car was derailed, the men passengers, even altho they were dressed in their Sunday best, left the car and helped the driver place it back on the rails.

There were no destination signs on the cars-the public having to be born with the knowlege of destination apparently-and there were no such things as transfers and schedules. All fares on all lines were a nickel; and a passenger who desired to reach a cer- 
tain destination which compelled him to ride on two different lines, had to pay a nickel on each line.

\section{Competrtion Brought Electrictry}

Dr. Turner, who even in those early days, had the difficulties well known to modern transit systems, protested to the city council, saying that he had an exclusive franchise for a line using horse-drawn cars. The courts upheld his contention and the other lines were forced out of business, with the exception of a Mr. Van Ginkel, and his associates, who evaded the court order by electrifying their lines.

In 1877, Mr. Van Ginkel, H. E. Teachout, and their associates secured a charter to lay a broad-gauge track. Under this franchise the new company had to use electric-powered street cars. This company erected a power plant on the east bank of the Des Moines river. Within a year's time this new company started the operation of electric cars. It is alleged that Des Moines was the third city to adopt electric power for the propulsion of street cars.

In 1888, Dr. Turner sold his share of the original company to Mr. Polk, and by 1889 , Mr. Polk had consolidated all the companies which had formerly operated lines in the city. Mr. Polk's company then equipped all lines with new track and installed electric trolley cars. Even in that early day the Polk company had nearly fifty miles of track and seventy-five street cars, which were then considered rapid transit, altho their scheduled speed was only five miles per hour compared to modern railways which operate from twelve to fifteen miles per hour.

By 1899, Mr. George Hippee, Mr. Polk's son-in-law, became active in the company, which continued to develop until by the turn of the century a large power house was in operation on the east bank of the Des Moines river, equipped with ten boilers, three engines, ten dynamos; and in addition the company had a large machine and car-building shop near the power plant.

Many of you remember Dan Finch, who was for a 
great number of years claim agent for the company. Dan was full of amusing and tragic stories about the operations of the company. One of his masterpieces concerned a man who was killed by being run over by a street car on Ingersoll avenue. Dan contended that he called the then superintendent of the property and notified him of the accident, stating that the man had no identification papers of any kind and that he could not identify him. The superintendent of the property said: "Well for God's sake take him out in the back yard and bury him before somebody enters a claim." So Dan proceeded to dig a hole in his back yard and disposed of the claimant in that manner.

Dan also loved to tell of the first electric car to be operated up the hill on West Fourth street. The then general manager of the property had tried out the electric car and had found it would operate and climb the steep incline. He then proceeded to place numerous bets that the electric car could climb the hill. Then came the day on which the car was to be placed in service, and the general manager invited all of his friends to take the first trip. He was absolutely confident that there would be no difficulty, but in his enthusiasm overloaded the car with free passengers. As a result, the car got halfway up the hill and then stalled, and the general manager paid off his bets with not too much enthusiasm.

\section{MaIl Boxes on Street Cars}

In the old days mail boxes were attached to each car; and when a person wished to mail a letter, he merely went out to the line, stopped the car and dropped his letter into the mail box.

In 1905 , the railway company had approximately 300 employees. In that same year the Unbandale line was completed.

In 1910, the East Fourteenth street line was laid, and in 1920, the Crocker line was built.

By 1911, there were 78.91 miles of track in operation and 103 cars on the lines. Today the railway company 
operates 225 vehicles and has well over 100 route miles of operation.

In 1911, the street railway system, then owned by the Harris Trust Company of Chicago, was petitioned into bankruptcy, and Mr. Emil Schmidt was appointed manager for the receiver. Mr. Schmidt later became president of the reorganized company and was succeeded by Frank Chambers.

In the early days about all employees of the company received fifteen cents per hour and worked ten hours per day. Under present conditions operators of the railway company receive $\$ 1.47$ per hour; work eight hours per day with time and one-half after eight hours, and time and one-half if they work on their scheduled day off. In addition, every employee of the railway company is given free of charge a $\$ 1,000$ life insurance policy, Blue Cross services for himself and his family, accident and health insurance, a pension of $\$ 50.00$ per month after twenty years of service, a two week's vacation with pay, increased to three weeks after fifteen years of continuous service, free transportation for himself and wife, and in many instances receives eight hours' pay for from two to four hours' actual work.

Between 1911 and 1929, continuous strife existed between the unions representing the men, and the company. These misunderstandings resulted in vicious and disorderly strikes. During the summer of 1921, service was discontinued for a period of four months; but during fair week of that year the men agreed to operate the cars for the fair week only.

In 1929, after a receivership, the present managment, headed by $\mathrm{C}$. W. Gifford, assumed control of the company and immediatly inaugurated one-man car service. From that date to 1948, no labor difficulties of any kind were encountered by the new management. In 1949, a misunderstanding occurred which resulted in a twenty-four-hour strike. This is the only labor diffi- 
culty encountered by the management in twenty-nine years of operation.

Under the administration of the present management, the system has been gradually changed from street cars operating on steel rails to rubber tires in the form of curbliners and motor coaches.

I am an enthusiastic street railway man and have a great interest in steel rail operation; but I must admit that the curbliners are far superior to any, even modern, street cars that were operated in Des Moines and elsewhere. I can honestly say that the present system operated by the Des Moines Railway company is one of the best systems in the entire United States.

\section{The Longings of Humanity}

Pres. Samuel N. Stevens, Grinnell College: The little understood factors in economic success are often confusing, in that people have different conceptions of what is success. Individuals think they are successful in some things, but find they are failures in others, not understanding that success after all is a condition of the mind. A correct definition of success is the will to achieve beyond any given level and a permanent self-analysis which keeps the individual whole in spite of pressures to divert.

Human beings may be classified into two categories: 1) the salesman type-those who have a desire for motivation, power and money, and 2) the educator type who desire service and security. All humanity has the feeling of wanting to "belong." This is the reason clubs and organizations are essential in our way of life, as there is the human need to have the sense of belonging. In order to promote and obtain better harmony between worker and employer management should recognize the employee for his ability and loyalty. This is to give the individual the personal feeling of success in his endeavors, and the feeling for community welfare, as well as the sense of fulfillment of aims in life.-Address to Des Moines Rotary Club. 
Copyright of Annals of Iowa is the property of State of Iowa, by \& through the State Historical Society of Iowa and its content may not be copied or emailed to multiple sites or posted to a listserv without the copyright holder's express written permission. However, users may print, download, or email articles for individual use. 